JURNAL PENDIDIKAN, p-ISSN 2715-095X, e-ISSN 2686-5041

Volume 29, No.3, Nopember 2020 (287-294)

Online: http://journal.univetbantara.ac.id/index.php/jp

\title{
Peningkatan Hasil Belajar IPS Melalui Model Pembelajaran Problem Based Learning Kelas IXD SMP Negeri 1 Tawangsari
}

\section{Muslimah}

Guru SMP Negeri 1 Tawangsari, Email: muslimahi597@mail.com

\begin{abstract}
Abstrak: Penelitian ini bertujuan untuk meningkatkan hasil belajar IPS melalui model pembelajaran kooperatif problem based learning pada siswa kelas IXD SMP Negeri 1 Tawangsari tahun pelajaran 2018/2019. Subjek penelitian Tindakan kelas ini adalah siswa kelas IXD SMP Negeri 1Tawangsari tahun pelajaran 2018/2019 sebanyak 32 siswa sebagai subjek penerima tindakan, sedangkan untuk subjek pelaku tindakan adalah guru IPS kelas IXD selaku guru, teman sejawat selaku subjek yang melakukan observasi proses pembelajaran, Kepala Sekolah selaku subjek sumber data. Metode pengumpulan data dilakukan melalui teknik tes, observasi dan dokumentasi. Penelitian Tindakan ini dilakukan dalam dua siklus, tiap-tiap siklus terdiri dari: perencanaan, tindakan, pengamatan dan refleksi. Hasil penelitian ini menunjukkan bahwa penggunaan model pembelajaran problem based learning dapat meningkatkan hasil belajar IPS siswa kelas IXD SMP Negeri 1 Tawangsari tahun pelajaran 2018/2019. Hal ini dapat dilihat dari nilai rata-rata hasil belajar IPS siswa juga mengalami peningkatan yaitu sebelum Tindakan sebesar 70,19, pada siklus I sebesar 76,38 , dan pada siklus II sebesar 82,28. Selain itu, presentase ketuntasan belajar siswa, yaitu sebelum Tindakan sebesar 34,38\%, pada siklus I sebesar $68,75 \%$ dan pada siklus II sebesar $96,88 \%$.
\end{abstract}

Kata-kata Kunci: pembelajaran kooperatif problem based learning dan hasil belajar IPS siswa.

\section{Improvement Learning Outcomes Social Sciences Using Problem Based Learning Method on The Students of Class IXD SMP Negeri 1 Tawangsari}

\section{Muslimah}

The Teacher of SMP Negeri 1 Twangsari,Email: muslimahi597@gmail.com

\begin{abstract}
The aim of this research is to improve learning outcomes socialscience through the problem based learning model in class IXD students of SMP Negeri 1 Tawangsari at academic year 2018/2019. The subject of this clssroom action student of IXD SMP Negeri 1 Tawangsari at academic year 2018/2019 as many as 32 student as the subject receiving action, while for the suject of the actionactor is IPS teacher class IXD as a teacher, peers as subjects who carry out observations learning process, the principal as the subject of the data source. Method of collecting data done through test techniques, obsevation and documentation. This action research was conducted in two cycles, each cycle consists of : planning, acting, observing, and reflecting the results of this study indicate that the useof lerning models can improve the learning outcomes IPS of IXD student of SMP Negeri 1 Tawangsari at academic year 2018/2019. There is an improvement learning outcomes social science achievement of average: 70.19 before the reserach, 76.38 after first cycle and 82.28 after the second cycle. Besides, the classical completeness average is also improved: $34.38 \%$ before the research , $68.75 \%$ after first cycle, and $96.88 \%$ after the second cycle.
\end{abstract}

Key words: problem based learning cooperative learning model type and achievement of studying science

\section{Pendahuluan}

Pembelajaran IPS di sekolah tidak berdiri sendiri sebagai sebuah mata pelajaran yang mandiri, melainkan menjadi bagian mata pelajaran IPS secara terpadu. Pembelajaran 
IPS terdiri dari pelajaran geografi, ekonomi, sejarah, sosiologi, dan anthropologi. Pembelajaran IPS yang tercantum dalam silabus kelas IX semester I pada standar kompetensi memahami kondisi perkembangan negara-negara di dunia kompetensi dasar mengidentifikasi negara berkembang dan negara maju. Melalui ketentuan tersebut, jelas bahwa siswa kelas IX semester I sudah seharusnya mampu menguasi kompetensi mengenai negara-negara di dunia baik yang masih tergolong negara berkembang dan juga bagi negara yang sudah maju. Untuk mencapai kompetensi dasar tersebut dibutuhkan Kerjasama baik dari guru, maupun siswa, serta instrument pendukung lainnya. Dalam kenyataan di lapangan, yang berkaitan dengan kompetensi tentang negara-negara di dunia pada siswa kelas IXD semester I SMP Negeri 1 Tawangsari masih rendah. Berdasarkan pengalaman penulis sebagai guru IPS, siswa kelas IXD SMP Negeri 1 tahun pelajaran 2018/2019 sebanyak 32 siswa ini dapat di kategorikan hasil belajar pada negara -negara di dunia masih rendah, hal ini dapat dilihat dari nilai rata-rata yaitu 50,59 dan yang sudah mencapai Kriteria Ketuntasan Minimal (KKM) sebanyak 11 siswa atau sebesar 34,38\% dari KKM yang telah ditentukan sebesar 75. Hal ini tentunya didasari oleh beberapa kendala. Kendala yang pertama adalah kurangnya motivasi belajar siswa terutama pada pembelajaran IPS karena siswa beranggapan bahwa pembelajaran IPS sulit karena banyak materi perlu dipahami dan bukan mata pelajaran yang uji secara nasional. Hal ini dapat dilihat dari hasil kuesioner atau angket siswa yang berkaitan dengan pembelajaran IPS dan hasilnya sebagian besar siswa kesulitan. Kendala kedua adalah tenaga pendidik. Dalam hal ini, yang bertindak sebagai tenaga pendidik adalah guru. Selama ini, guru hanya bertindak sebagai penyampai pesan saja tanpa memperhatikan tanggapan siswater hadap pembelajaran yang disampaikan. Guru juga kurang memanfaatkan metode pembelajaran, dan media yang ada untuk menunjang proses pembelajaran agar tingkat pencapaian kompetensi dasar dapat maksimal. Apabila guru mampu memanfaatkan metode pembelajaran dan media yang ada dengan baik dan sesuai, maka pencapain kompetensi dasar yang diharapkan dapat tercapai. Hal ini tentunya dapat meningkatkan hasil belajar siswa.

Untuk itu, peneliti mencoba menerapkan metode Problem Based Learning untuk mengatasi kesulitan yang dialam isiswa dalam mempelajari negara berkembang, karena siswa akan lebih tertarik dalam mengikuti proses pembelajaran yang berlangsung yang sudah disiapkan guru yang berkaitan dengan kompetensi dasar yang ingin dicapai. Metode pembelajaran Problem Based Learning (PBL) ini menggunakan media gambar yang sudah disesuaikan dengan tujuan pembelajaran. Menurut Dewey dalam Trianto (2007 : 67), belajar berdasarkan masalah adalah interaksi antara stimulus dengan respons, merupakan hubungan antara dua arah belajar dan lingkungan. Manfaat yang diperoleh dari model pembelajaran PBL membantu memberi motivasi siswa terlibat dalam pembelajaran sehingga pembelajar bisa lebih menarik dan menyenangkan. Berdasarkan latar belakang tersebut maka dalam penelitian ini dapat dipaparkan bagaimana guru dapat meningkatkan hasil belajar siswa dalam pembelajaran kompetensi negara-negara di dunia melalui model pembelajaran PBL pada siswa kelas IXD semester I SMP Negeri 1 Tawangsari.

\section{Metode Penelitian}


Penelitian ini adalah Penelitian Tindakan Kelas (PTK), merupakan suatu pencermatan terhadap kegiatan yang sengaja dimunculkan, dan terjadi dalam sebuah kelas (Arikunto, 2010: 130).Penelitian ini dilaksanakan di SMP Negeri 1 Tawangsari.Tahap-tahap pelaksanaan kegiatan dilakukan selama kurang lebih enam bulan yaitu sejak bulan Juli sampai dengan bulan Desember 2018. Subjek penelitian tindakan kelas ini adalah siswa kelas IXD SMP Negeri 1 Tawangsari semester 1 tahun pelajaran 2018/2019 sebanyak 32 siswa yang terdiri dari 15 siswa laki-laki dan 17 siswa perempuan sebagai subjek penerima tindakan, sedangkan untuk subjek pelaku Tindakan adalah guru IPS kelas IXD selaku guru, teman sejawat selaku subjek yang melakukan observasi proses pembelajaran, Kepala Sekolah selaku subjek sumber data. Metode pengumpulan data dilakukan melalui Teknik tes, observasi dan dokumentasi. Teknik pengumpulan data yang digunakan adalah: (a) Tes, observasi, dan dokumentasi. Metode tes digunakan untuk memperoleh data tentang hasil belajar IPS siswa sebelum penelitian, selama penelitian dan setelah penelitian dilaksanakan. Observasi yang digunakan adalah observasi sistematis, yaitu observasi yang dilakukan oleh pengamat dengan menggunakan pedoman sebagai instrumen pengamatan. Instrumen yang digunakan dalam penelitian ini adalah: lembar observasi, tes, dan dokumentasi.Lembar observasi digunakan peneliti sebagai pedoman melakukan observasi atau pengamatan guna memperoleh data yang akurat dalam pengamatan. Lembar observasi juga digunakan untuk memonitor dan mengevaluasi setiap tindakan agar kegiatan observasi tidak terlepas dari konteks permasalahan dan tujuan penelitian. Tes digunakan untuk melihat seberapa besar penguasaan konsep IPS siswa terhadap materi yang diajarkan.Hasil tes dianalisis guna mengetahui penguasaan materi IPS setelah dilakukan model pembelajaran problem based learning Indikator keberhasilan dalam penelitian ini adalah apabila nilai rata-rata tessiswa sekurang-kurangnya 80,0 dan banyak siswa dengan nilai di atas batas KKM yaitu $\geq 75,0$ mencapai $\geq 90 \%$.

\section{Hasil dan Pembahasan}

Berdasarkan hasil belajar prasiklus dari 32 siswa yang mencapai nilai kriteria ketuntasan minimal (KKM) yaitu 75 sebanyak 11 siswa $(34,38 \%)$ dan siswa yang tidak mencapai nilai kriteria ketuntasan minimal (KKM) sebanyak 21 siswa (65,63\%) dengan

nilai rata-rata kelas sebesar 70,19. Guru hanya menerapkan model ceramah dan siswa hanya disuruh mendengarkan dan mencatat apa yang diperlukan. Hasil ini dapat ditampilkan pada grafik berikut. 


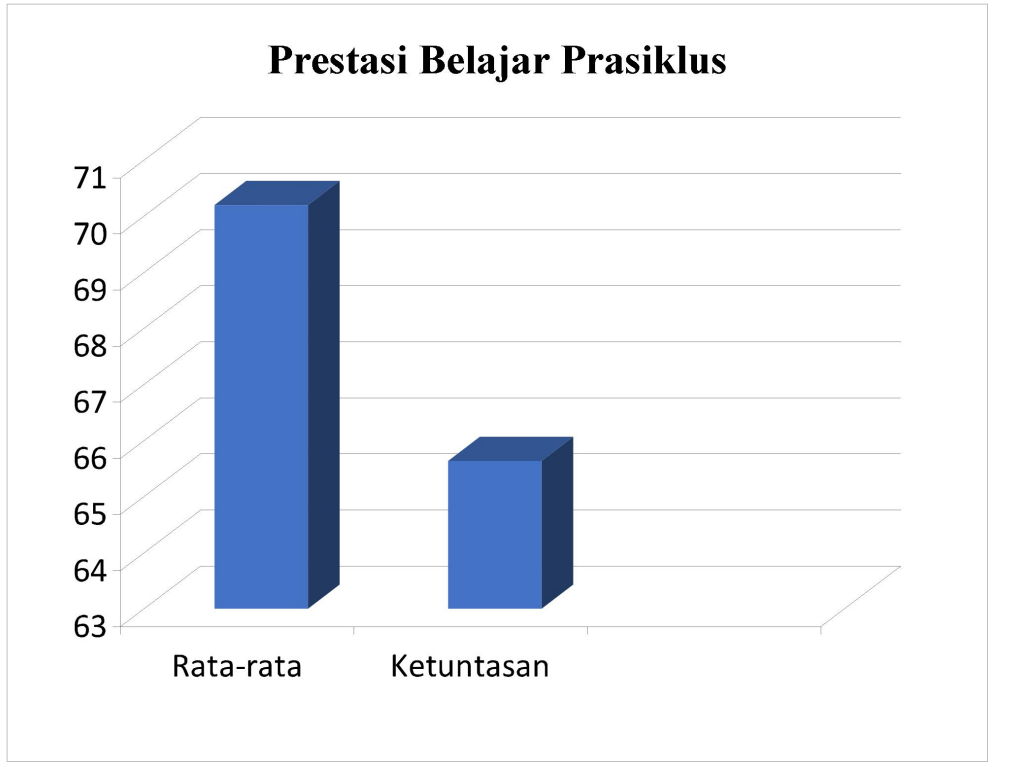

Gambar 1.Grafik Prestasi belajar IPS Siswa pada Prasiklus

Pembelajaran dilaksanakan dengan pedoman Rencana Pelaksanaan Pembelajaran selama 2 kali pertemuan ( 2 x 80 menit). Kompetensi Dasar yang disampaikan pada siklus I adalah materi negara maju dan berkembang di dunia. Setelah langkaha persepsi dilanjutkan dengan penyampaian materi dengan model pembelajaran tipe PBL. Model pembelajaran tipe PBL dilaksan akan dengan menggunakan langkah-langkah sebagai berikut: (1) Pendahuluan berisi kegiatan guru memberi salam, mengkondisikan kelas, dan mengecek presensi siswa. Guru menyampaikan tujuan pembelajaran yang ingin dicapai dan memberimotivasi belajar; (2) Kegiatan inti tentang pelaksanaan kegiatan model pembelajaran kooperatif tipe PBL sebagai berikut: Guru membagi siswa menjadi 5 kelompok secara heterogen dan juga nilai tes sebagai dasar dalam menentukan kelompok. Guru menentukan materi pelajaran dan mengundi setiap kelompok untuk mencari keterangan sesuai dengan masalah memberikan. Setiap kelompok mendiskusikan masalahnya dan mengumpulkan informasi sesuai dengan tugasny. Setiap kelompok mengumpulkan hasil diskusi dalam bentuk laporan.Guru juga memberi kesempatan kepada siswa untuk menyampaikan pendapat atau pengalaman yang berkaitan dengan materi yang didiskusian. Guru menunjuk salah satu kelompok mempresentasikan hasil diskusinya dan secara bergantian setiap kelompok mempresentasikan hasil diskusinya di depan kelas dengan penjelasan masalah yang dipecahkan bersama kelompoknya. (3) Kegiatan penutup Guru memfasilitasi siswa membuat rangkuman, mengarahkan dan memberikan penegasan dan kesimpulan pada materi negara maju dan negara berkembang di dunia. Guru memberikan kuis kepada siswa secara individu dan memberikan penghargaan pada kelompok perolehan nilai hasil dari skor dasar ke berikutnya.Guru materi pertemuan kepada siswa dan

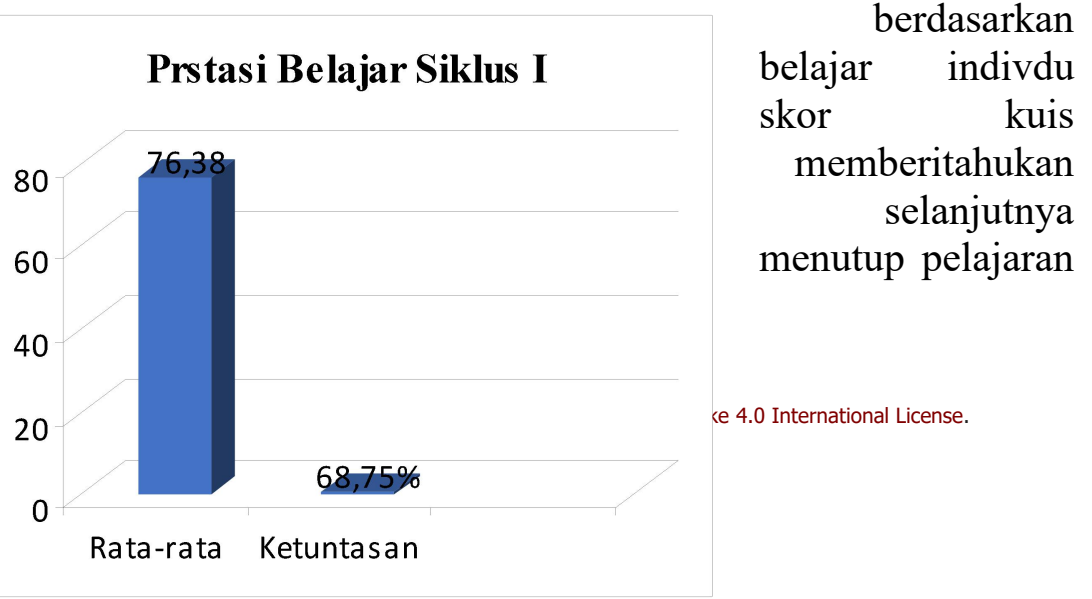


dengan berdoa. Hasil observasi menunjukkan bahwa guru telah melaksanakan kegiatan pembelajaran dengan cukup baik, yaitu guru mengajar dengan arah dan tujuan yang jelas. Namun ketika guru menyampaikan materi dengan model pembelajaran kooperatif tipe PBL beberapa siswa tampak masih kurang memperhatikan, dan beraktivitas sendiri. Selain itu tidak semua kelompok dapat berdiskusi dengan baik. Berdasarkan hasil evaluasi pada siklus I menunjukkan adanya peningkatan hasil belajar siswa. Rata-rata hasil belajar siswa pada siklus I adalah 76,38, sebanyak 22 siswa $(68,75 \%)$ mencapai nilai KKM, dan sebanyak10 siswa $(31,25 \%)$ tidak mencapai nilai KKM.

Gambar 2.GrafikPrestasibelajarIPSSiswa pada Siklus I

Keberhasilan yang dicapai setelah siklus I hanya sebagian siswa yang menunjukkan partisipasi yang meningkat sementara siswa lainnya masih pasif. Refleksi terhadap faktorfaktor yang menjadi penyebab kurangnya partisipasi siswa adalah: (1) Sebagiansiswa belum bisa mengikuti langkah-langkah pembelajaran model pembelajaran kooperatif tipe PBL; (2) Kerjasama dalam kelompok berdiskusi belum maksimal; (3) Hanya siswa tertentu saja yang dapat memahami materi dan mencari solusi pemecahan masalah yang diberikan kepada setiap kelompok.

Pembelajaran dilaksanakan dengan pedoman Rencana Pelaksanaan Pembelajaran selama $2 \mathrm{x}$ pertemuan $(2 \mathrm{x}$ 80menit).Setelah langkaha persepsi dilanjutkan dengan penyampaian materi dengan model pembelajaran tipe PBL. Pada pelaksanaan siklus II ini, kegiatan pembelajaran dilaksanakan dengan proses sebagai berikut. (1) Guru mengulang sekilas materi yang telah disampaikan kemudian melanjutkan materi yang baru dengan model pembelajaran kooperatif tipe PBL seperti pada siklus I, tetapi jumlah anggota kelompok 4 siswa engan materi perang dunia II dan kependudukan Jepang di Indonesia (2) Guru memberikan latihan soal-soal dengan model pembelajaran kooperatif tipe PBL; langkah selanjutnya seperti pada siklus I; (6) Guru memberikan postest dan tugas rumah. Berdasarkan kegiatan observasi, secara garis besar diperoleh gambaran pelaksanaan 
tindakan siklus II ada peningkatan hasil belajar siswa. Dalam pertemuan ini banyak siswa mampu menjawab soal-soal yang diberikan dengan benar dan baik. Sebagian siswa aktif dalam bertanya dan mengemukakan ide mereka. Siswa juga dapat memahami materi yang telah diajarkan hal ini terlihat dari cara siswa menyelesaikan soal-soal. Berdasarkan hasil evaluasi pada siklus II menunjukkan adanya peningkatan hasil belajar siswa. Rata-rata prestasi belajar siswapada siklus II adalah 82,28 sebanyak 31 siswa (96,88\%) mencapai nilai KKM, dan sebanyak1 siswa $(3,13 \%)$ tidak mencapai nilai KKM. Hasil ini dapat ditampilkan pada grafik berikut.

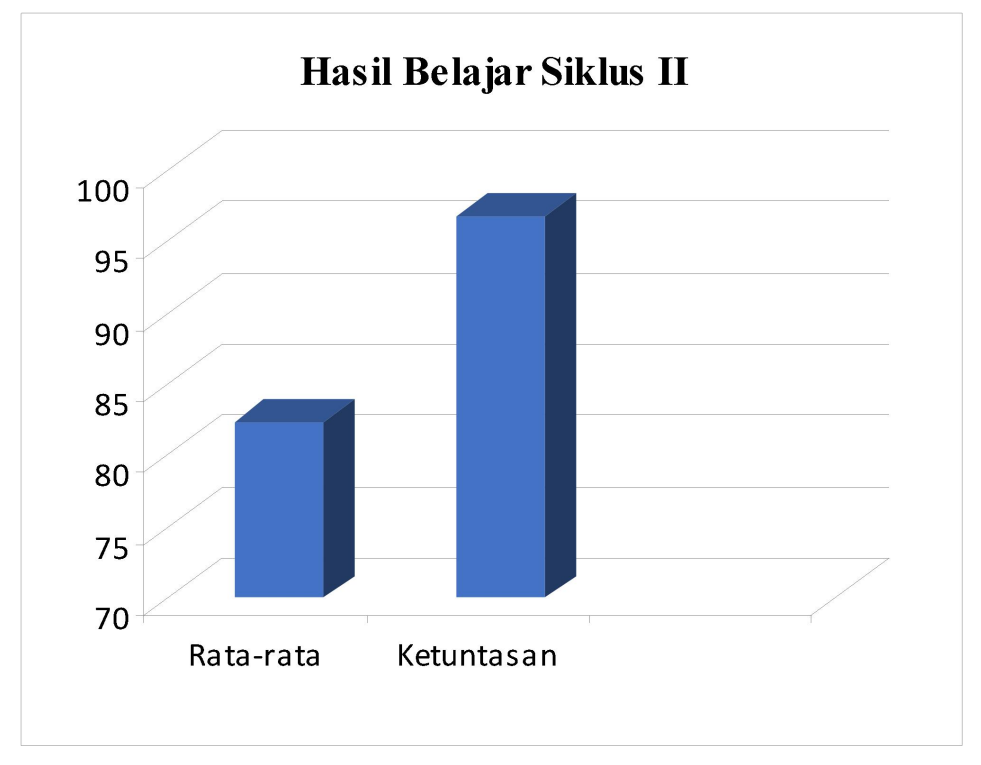

Gambar 3.GrafikPrestasibelajarIPSSiswa pada Siklus II

Sebagian siswa menunjukkan partisipasinya meningkat dari siklus II . Keberhasilan yang dicapai setelah siklus II telah memenuhi indikator keberhasilan penelitian ini, sehingga tindakan ini tidak diteruskan atau dihentikan pada siklus II. Berdasarkan pengolahan dan analisis data di atas, maka diperoleh interpretasi bahwa penerapan model pembelajaran kooperatif tipe problem based learning terhadap peningkatan hasil belajar siswa menunjukkan bahwa terjadi peningkatan hasil belajar siswa pada sebelum tindakan siklus I, dan pada siklus I ke siklus II. Terjadi peningkatan hasil belajar siswa ini sebagai efek dari meningkatkan keterampilan sosial dan kemandirian siswa yaitu adanya perhatiaan siswa dalam proses belajar, kerjasama dalam tiap pasangan kelompok dan kemandirian dalam mengerjakan soal. Hal ini dapat dilihat dari hasil penelitian dari siklus pertama sampai dengan siklus kedua dapat diringkaskan seperti terlihat pada table sebagai berikut:Hasil analisis evaluasi yang dilaksanakan pada setiap siklus diperoleh peningkatan hasil belajar siswa.Hal ini dapat dilihat pada nilai rata-rata siswa dan persentase ketuntasan hasil belajar siswa pada setiap siklus yang mengalami peningkatan.

Tabel 1.Peningkatan Hasil BelajarPraSiklus, Siklus I, dan Siklus II

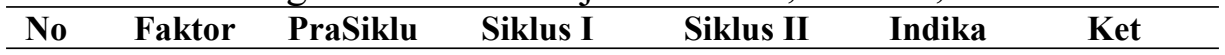




\begin{tabular}{|c|c|c|c|c|c|c|}
\hline & \multicolumn{3}{|c|}{$\mathbf{s}$} & \multicolumn{3}{|c|}{ tor } \\
\hline 1 & $\begin{array}{c}\text { Rata-rata } \\
\text { kelas }\end{array}$ & 70,19 & 76,38 & 82,28 & $\geq 80,00$ & Tercapai \\
\hline 2 & $\begin{array}{l}\text { Ketuntas } \\
\text { anbelajar }\end{array}$ & $34,38 \%$ & $68,75 \%$ & $96,88 \%$ & $90,62 \%$ & Tercapai \\
\hline
\end{tabular}

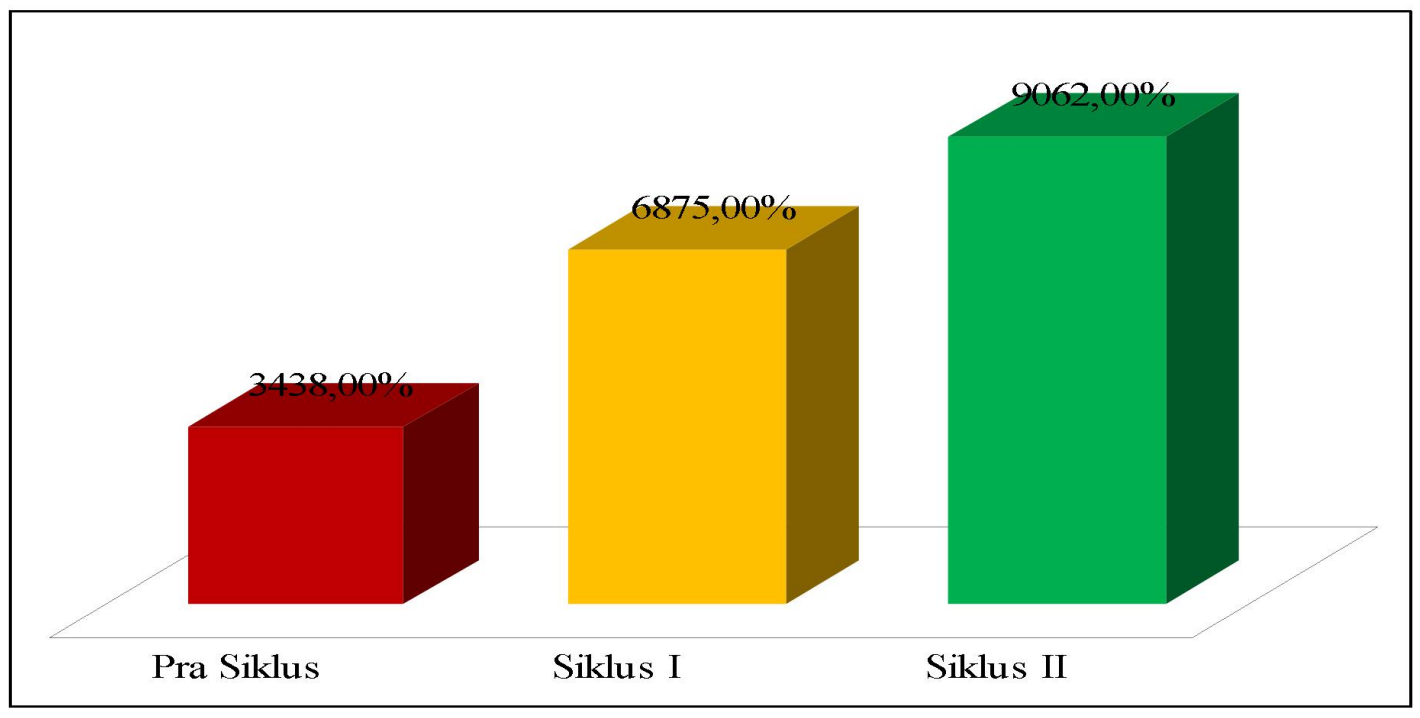

Gambar 4. GrafikPerbandinganKetuntasanBelajarSiswa

Dari tabel dangrafik di atas dapat disimpulkan bahwa prestasi belajar IPS siswa dengan menerapkan model pembelajarankooperatif tipe problem based learning di setiap putaran mengalami peningkatan, yaitu: (1) Sebelum dilakukan tindakan, nilai rata-rata hasil belajar siswa adalah 70,19 sedangkan persentase ketuntasan 34,38\%; (2) Setelah dilakukan tindakan pada siklus I, nilairata-rata hasil belajar IPS siswa mengalami peningkatan yaitu 76,38 dengan persentase ketuntasan 68,75\%, tetapi belum mencapai indikator yang diharapkan; (3) Pada siklus II, nilaihasil belajar siswa meningkat yaitu menjadi 82,28 dengan persentase ketuntasan sebesar 96,88\% dan sudah mencapai indikator yang diharapkan maka penelitian tindakan kelas ini sudah berhasil. Rata-rata hasil belajar IPS siswa padas iklus II sebesar 82,28 $\geq 80,0$ (indikator kinerja) dan persentase ketuntasan siklus II sebesar 96,88\% $\geq 90 \%$ (indikatorkinerja). Jadi, indikator kinerja sudah tercapai sehingga tidak dilanjutkan ke siklus berikutnya.

\section{Simpulan dan Saran}

Penggunaan model pembelajaran kooperatiftipe problem based learning dapat meningkatkan hasil belajar IPS siswa kelas IXD SMP Negeri 1 Tawangsari tahun pelajaran 2018/2019. Hal ini dapat dilihat dari nilai rata-rata hasil belajar IPS siswa juga mengalami peningkatan yaitu sebelum Tindakan sebesar 70,19 pada siklus I sebesar 76,38 dan pada siklus II sebesar 82,28. Selain itu, presentase ketuntasan belajar siswa, yaitu sebelum 
tindakan sebesar 34,38\%, pada siklus I sebesar $68,75 \%$ dan pada siklus II sebesar $96,88 \%$. Berdasarkan hasil dari simpulan di atas maka peneliti memberikan saran-saran sebagai berikut: (1) Agar para guru di SMP Negeri 1 Tawangsari dalam pelaksanaan pembelajaran IPS menerapkan metode problem based learning untuk meningkatkan hasil belajar IPS siswa kelas IX, (2) Siswa disarankan agar lebih aktif dalam pembelajaran baik secara individu maupun kelompok dalam pelaksanaan pembelajaran IPS menggunakan metode problem based learning, dan (3) Sekolah dapat mengambil kebijakan agar para guru di SMP Negeri 1 Tawangsari selalu menggunakan model pembelajaran yang inovatif dan menyenangkandalam proses belajar mengajar untuk meningkatkan hasil belajar siswa.

\section{Daftar Rujukan}

Trianto. (2007). Model-model Pembelajaran Inovatif Berorientasi Konstruktivistik. Jakarta :Prestasi Pustaka.

Isjoni. (2010). Cooperatif Learning Efektifitas Pembelajaran Kelompok. Bandung :Alfabeta. Huda, M. (2011). Cooperative Learning. Yogyakarta: Pustaka Belajar.

Sunartombs. (2011).Faktor - faktor yang mempengaruhi hasil belajar. From http:// sunartombs. wordpress. com/2011/10/10/faktor-yang-mempengaruhi-hasilbelajar/html. [Sabtu, 4 Februari 2012]

Indra, M. (2009). Pengertian dan Definisi Hasil Belajar. Fromhttp: //indramunawar .blogspot.com/2009/06/hasil-belajar-pengertian-dan-definisi.html . [Minggu, 11 Desember2011].

Sanjaya, A. Pengertian Definisi Hasil Belajar. From http://aadesanjaya. blogspot.com/2011/03/pengertian-definisi-hasil-belajar.html. [Sabtu, 28 Januari 2012].

Suyono \& Hariyanto. (2011). Belajar dan Pembelajaran. Bandung :RemajaRosdakarya.

Adenbagoes. (2011). Pengertian Belajar dan Hasil Belajar. From http://id.shvoong.com/social-sciences/education/2215837-pengertian-minat-belajardan-hasilhtml. [ Minggu, 11 Desember2011 ]. 